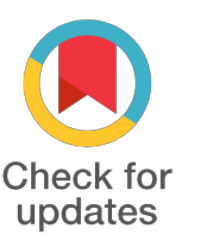

*For correspondence:

nvthuan@hcmiu.edu.vn

Competing interests: The authors declare that no competing interests exist.

Received: 2017-07-15

Accepted: 2017-08-05

Published: 2017-09-05

Copyright The Author(s) 2017. This article is published with open access by BioMedPress (BMP).

This article is distributed under the terms of the Creative Commons Attribution License (CC-BY 4.0) which permits any use, distribution, and reproduction in any medium, provided the original author(s) and the source are credited.

\section{Effects of biotin supplementation on the in vitro maturation of oocytes and the development of parthenogenetic diploid porcine embryos}

\author{
Nguyen Ba Tư ${ }^{1,2}$, Bui Hong Thuy ${ }^{1}$, Nguyen Van Thuan ${ }^{1}$ \\ ${ }^{1}$ Cellular Reprogramming Laboratory, Department of Biotechnology, School of Biotechnology, \\ HCMC International University - Vietnam National University, Viet Nam \\ ${ }^{2}$ Thu Dau Mot University, Viet Nam
}

\begin{abstract}
In mammals, Biotin serves a coenzyme in the metabolism of glucose, amino acids, and fatty acids. Biotin deficiency causes decreased rates of cell proliferation, disfunction in germ cells and fetal development. This study was carried out to determine the influence of Biotin supplementation to invitro maturation medium on the development of porcine oocyte and embryos. Biotin (0.0, 1.0, $10.0,100.0 \mathrm{mg} / \mathrm{l}$, respectively) was added into the oocyte maturation medium, the quality of mature oocytes was evaluated after $42 \mathrm{~h}$ culturing. The parthenogenetic diploid embryos were produced by using electro-activation system, the quality of embryos was noted at 1-4 cells stage. The results showed that, Biotin can enhance the formation of the first polar body at the concentration of $10 \mathrm{mg} / \mathrm{l}$, it can also improve the activation efficiency of parthenogenetic diploid embryos at the preimplantation stage from 2-4 cells. Therefore, the supplementation of 10mg/l Biotin to the in-vitro maturation medium has a beneficial effect on the parthenogenetic diploid embryos development in the pig.
\end{abstract}

\section{Keywords}

Biotin; IVM; porcine oocyte; parthenogenetic diploid embryos

Funding

\section{References}

